\title{
GUSTAVE FLAUBERT No BRASIL
}

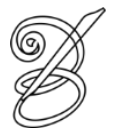 \\ Denise Bottmann \\ (Mestre, historiadora, tradutora) \\ dbottmann@gmail.com
}

Resumo: Este artigo apresenta um levantamento das traduções brasileiras de obras de Flaubert, desde sua primeira publicação em livro em 1932 até a data atual.

Palavras-chave: Gustave Flaubert, tradução literária, história da tradução no Brasil.

Abstract: This short essay lists Flaubert's writings translated and published in Brazil, since 1932 through 2012.

Keywords: Gustave Flaubert, literary translation, history of translation in Brazil.

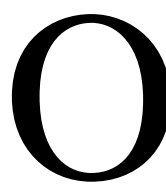

ano de ingresso da obra de Gustave Flaubert no Brasil, em tradução brasileira, é um pouco incerto.

Deve-se levar em conta que, até a época da grande crise de 1929, a imensa maioria

das obras traduzidas para o português era importada de Portugal. Apenas na esteira da quebra das importações na década de 1930 é que se tem um arranque editorial expressivo no país, alavancando também traduções nacionais.

Assim, embora Flaubert já fosse conhecido entre nós, tanto no original quanto em tradução, não é de admirar que a primeira edição brasileira de uma obra sua tenha saído apenas em 1931. Tratava-se de Madame Bovary, publicada pela Waismann em sua Coleção "Obras Célebres", em tradução "revista" pelo poeta e escritor mineiro Renato Travassos, sem menção ao nome do tradutor efetivo. No jargão editorial, "tradução revista" costuma indicar o uso de alguma tradução anterior, geralmente não especificada e muitas vezes de origem portuguesa. Aqui, portanto, não me parece improvável que se tratasse de uma tradução lusitana adaptada ao português brasileiro. Apresentei um rastreamento possível em <http://naogostodeplagio.blogspot.com.br/2012/10/como-e-quando-madame-bovary-chegaao.html>.

Quanto às primeiras traduções efetivamente brasileiras de Flaubert, há em nossos acervos na Biblioteca Nacional duas obras que parecem ser boas candidatas ao título. Infelizmente, não trazem o nome de quem as traduziu. São Salambô, pela Guanabara, em 
1932, e com data um pouco incerta (c. 1934), Madame Bovary, pela Sociedade Impressora Paulista.

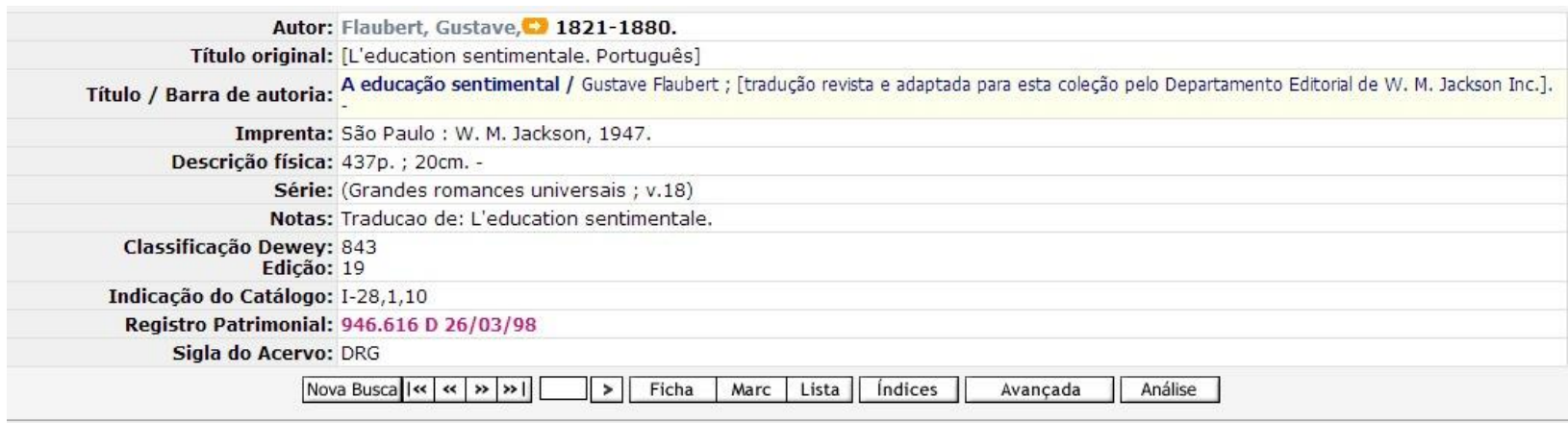

Autor: Flaubert, Gustave, 1821-1880.

Título / Barra de autoria: Madame Bovary.

Imprenta: S. Paulo, Impressora paulista, [1934?].

Descrição física: $345 \mathrm{p}$.

Notas: Registro Pré-MARC

Classificação Dewey: 843

Edição:

Indicação do Catálogo: 843/F587m7/1934

Por volta de 1942, a Livraria Martins Editora publica a coletânea intitulada Trois contes, em tradução de Galeão Coutinho. A obra sai com o título de São Julião, o hospitaleiro, contendo os outros dois contos da coletânea flaubertiana, a saber, "Herodíade" e "Um coração simples". Aliás, a Martins incluiu essa "Herodíade" em suas Obras-primas do conto francês, de 1958.

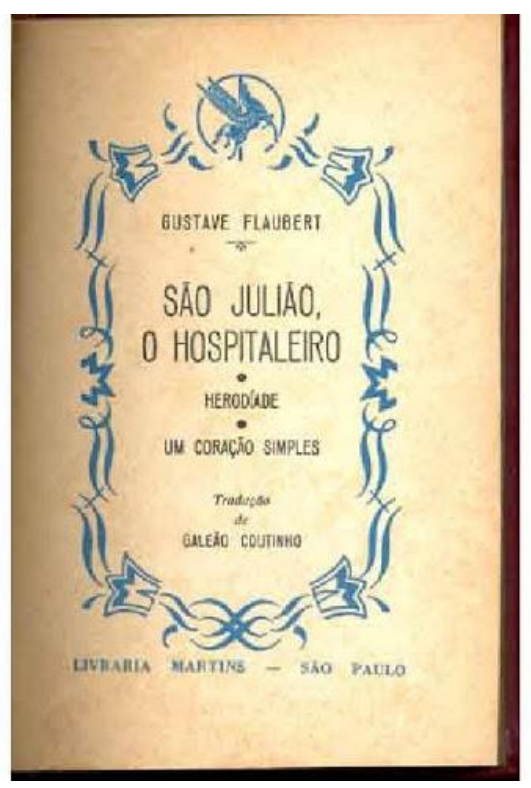


Também em 1942, aparece uma Salambô pela Pongetti, com "tradução revista" por Marques Rebelo. Ainda que, como afirmei acima, as ditas "traduções revistas" muitas vezes tomassem por base traduções portuguesas, nos anos 1940 a Pongetti começou a utilizar traduções brasileiras mesmo, tomando-as sem licença e entregando-as a algum escriba para "revê-las", papel a que Marques Rebelo se prestou com certa assiduidade. Foi o que ocorreu, por exemplo, com a tradução de Werther de Goethe, feita por Elias Davidovitch, publicada pela Guanabara em 1932 e apropriada pela Pongetti em 1943, "revista” por Marques Rebelo. Assim, não me parece improvável que a Pongetti tenha utilizado a tradução de Salambô publicada pela Guanabara em 1932, mas resta confirmar tal hipótese. De qualquer forma, essa questionável "tradução revista" continua em viçosa circulação até hoje, pela Ediouro.

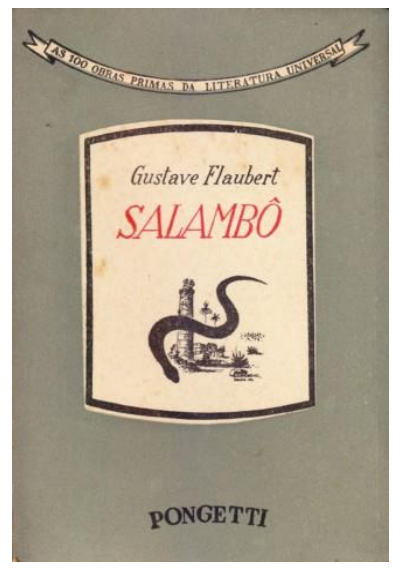

Fiel a seu sistema, a Pongetti lança logo a seguir, em 1944, uma Educação sentimental também em "tradução revista", agora por Araújo Alves. Tal como Salambô, ela continua até hoje em ativa circulação, também pela Ediouro:

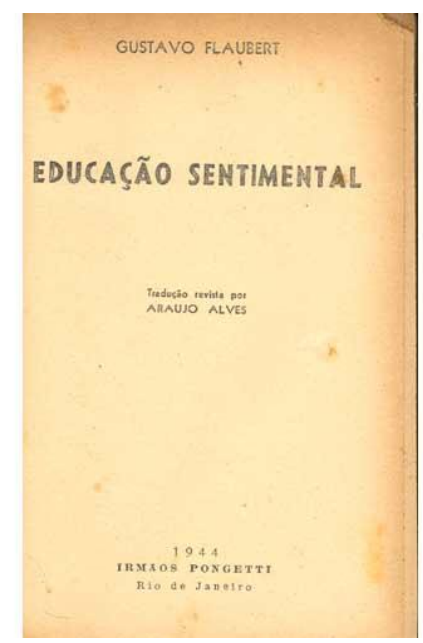


Ainda em 1944, a Editora Vecchi lança uma Madame Bovary, em sua Coleção "As Obras Eternas". Agora devidamente creditada, a tradução é de Eloy Pontes. A edição vem acompanhada pela requisitória, razões e julgamento do processo por obscenidade intentado contra o autor perante o Tribunal Correcional de Paris.

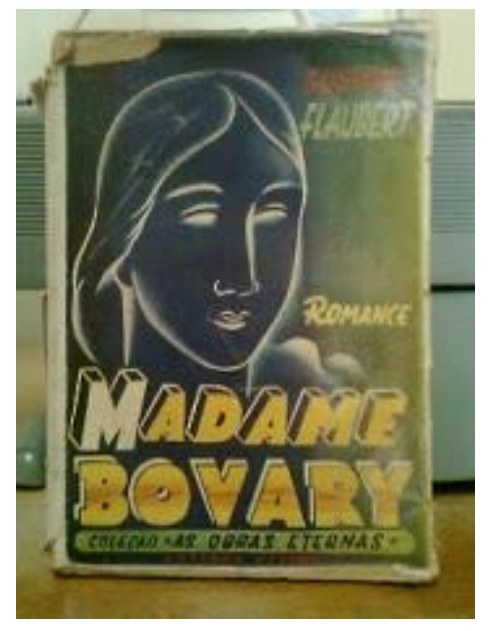

Continuando em 1944, o Clube do Livro lança uma Madame Bovary sem especificação dos créditos de tradução. O Clube do Livro era ainda mais vezeiro em lançar mão de traduções preexistentes e publicar contrafações anônimas (e, mais tarde, atribuindo-as com frequência a José Maria Machado). Porém costumava dar preferência a traduções publicadas em Portugal.

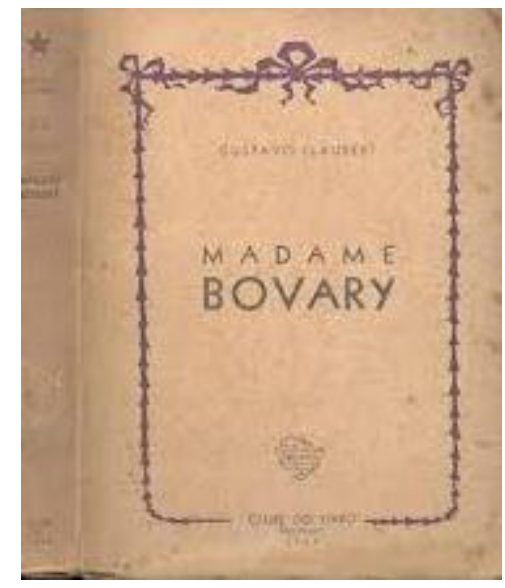


Ainda o Clube do Livro se sai em 1945 com uma Salambô no mesmo estilo, sem créditos de tradução:

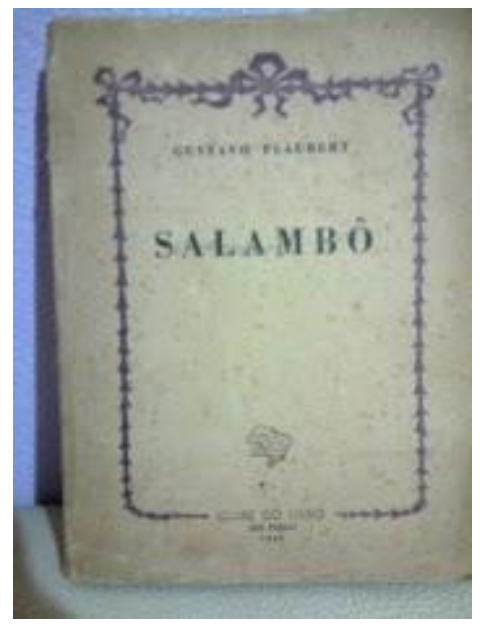

Em c. 1945 a Livraria Martins publica a tradução de Araújo Nabuco para Madame Bovary. Essa tradução teve amplíssima circulação ao ser licenciada para a Abril Cultural nos anos 1970 e 1980 e para o Círculo do Livro nos anos 1970 a 1990. Ainda hoje, ela circula pela Itatiaia e pela Martin Claret (não sei se com o devido licenciamento). Diga-se de passagem que a Madame Bovary de Araújo Nabuco foi protagonista de uma das fraudes mais cabeludas na história do plagiato tradutório nacional, às mãos da Editora Nova Cultural, em sua Coleção “Obras Primas" de 2002-2003.*1

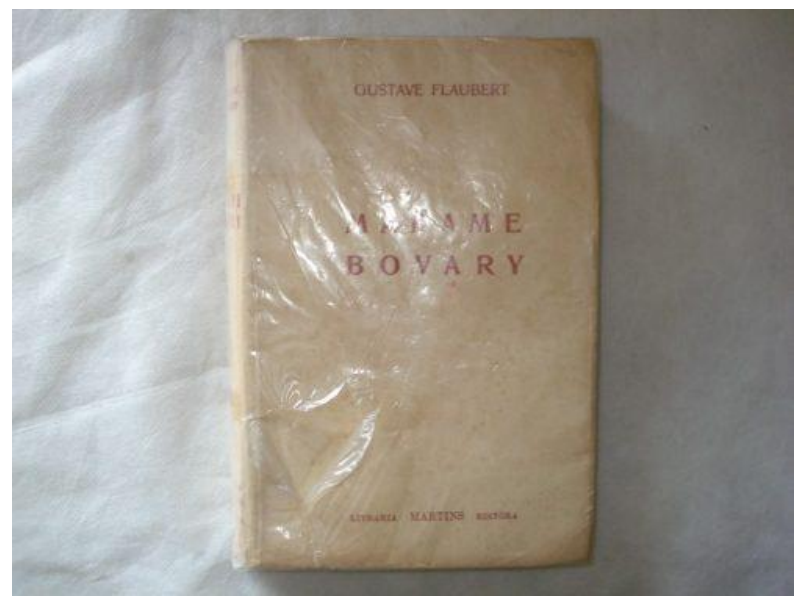


Em 1947, é a vez da W. M. Jackson de "revisar" e "adaptar" uma tradução não identificada d'A educação sentimental:
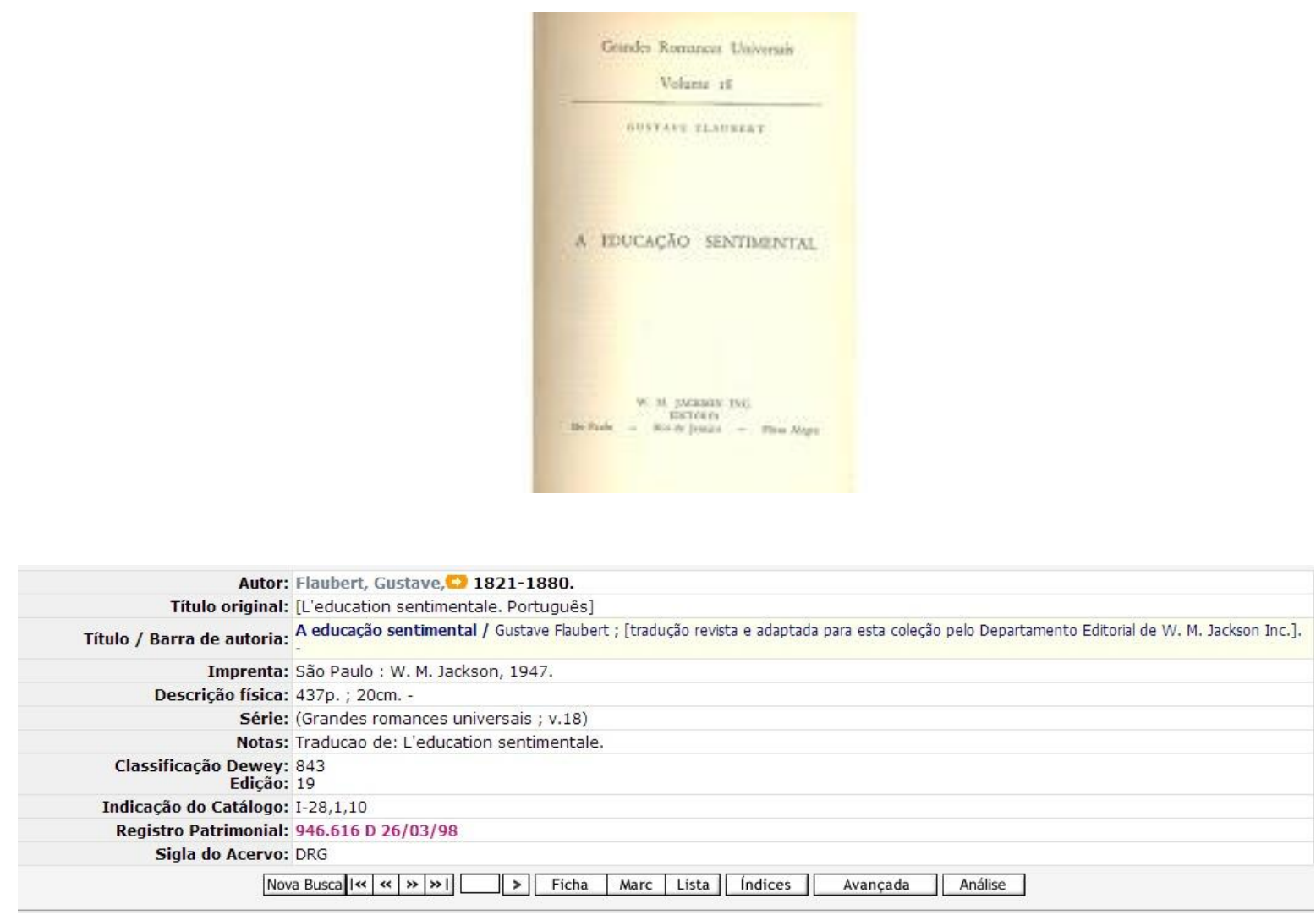

A partir de 1948, vale a pena nos concentrarmos na editora que realmente se dedicou a divulgar com constância e seriedade as obras principais de Flaubert no Brasil: a Melhoramentos. Temos, em sequência, sempre pela Melhoramentos:

- $\quad$ 1948, A educação sentimental, em tradução de Mirinha de Lacerda Soares:

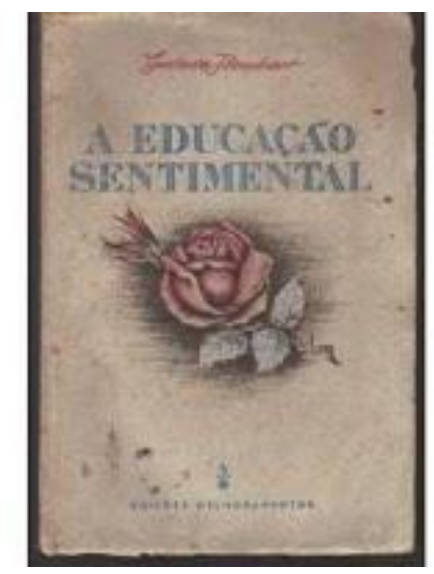


- 1949, Salambô, em tradução de Aloysio Ferraz Pereira (aqui na capa da edição de 1956):

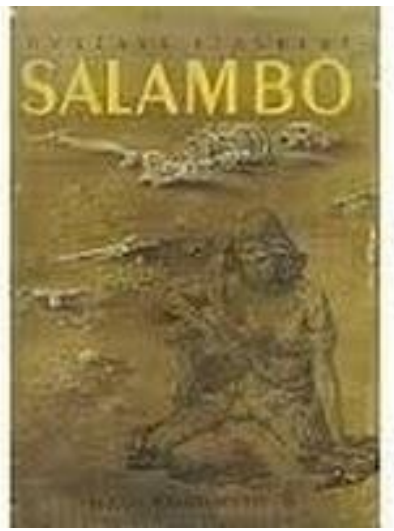

- 1950, Madame Bovary: costumes de província, em tradução de Genésio Cândido Pereira Filho:

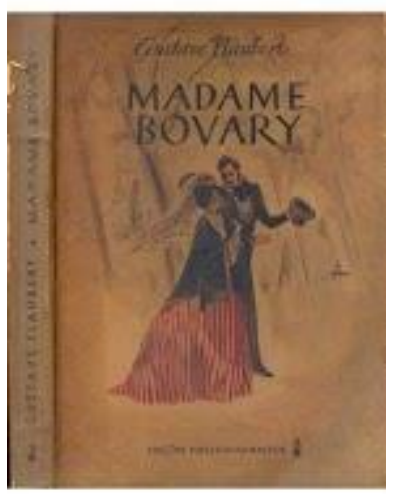

- 1956, Três contos (“Um coração simples”, “A lenda de são Julião, o hospitaleiro" e "Herodias"), em tradução de Carlos Chaves, aqui em capa de 1960:

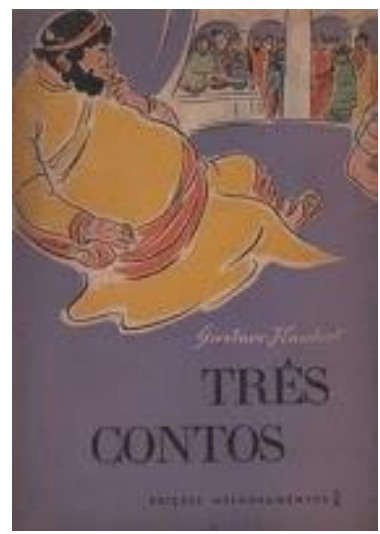


- 1957, A tentação de santo Antão, em tradução de Carlos Chaves:

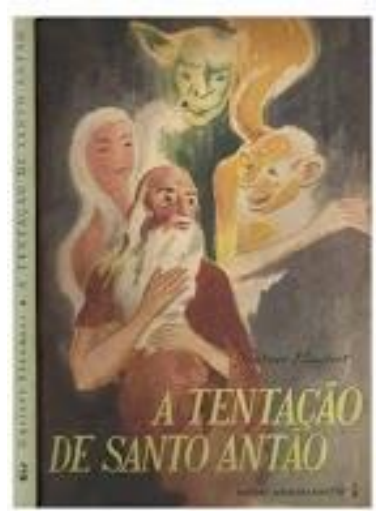

- 1960, Bouvard e Pécuchet, seguido de Dicionário de ideias feitas, em tradução de Galeão Coutinho e Augusto Meyer. Como Galeão Coutinho morreu prematuramente num trágico acidente de avião, em 1951, parece plausível supor que Augusto Meyer tenha terminado uma tradução inacabada.

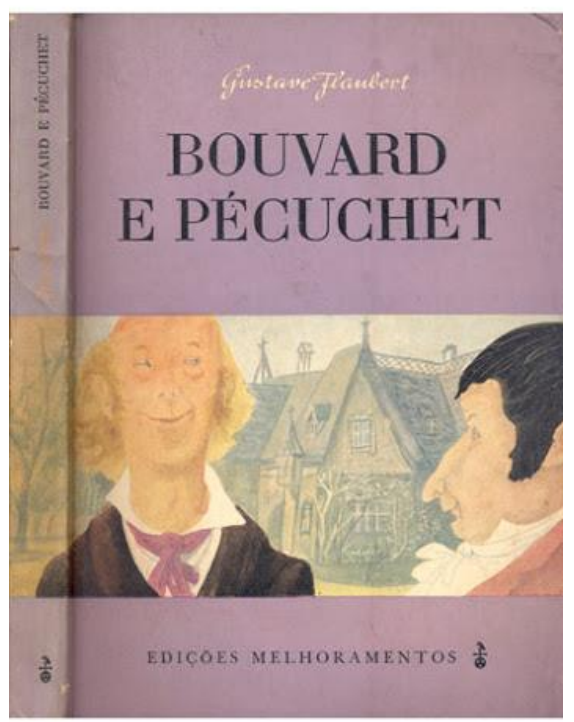

Nunca será demais reconhecer essa iniciativa da referida editora, e com traduções de boa a ótima qualidade.

No interregno de 1948 a 1960, quando as publicações de Flaubert se concentram basicamente na Melhoramentos, temos apenas duas outras edições. Uma delas, na verdade, é uma mera reedição no Clube do Livro, relançando a tradução de Galeão Coutinho, que saíra pela Martins em c. 1942, com os mesmos contos lá acima citados. A outra, esta sim importante, é A educação sentimental: história de um moço, com tradução de Adolfo Casais Monteiro (português, mas radicado no Brasil). Saiu em 1959, 
em dois volumes, na Coleção “Clássicos Garnier” da DIFEL (Difusão Europeia do Livro). Essa tradução terá grande permanência entre nós, com inúmeras edições pela Abril Cultural, Círculo do Livro e, mais recentemente, pela Nova Alexandria.

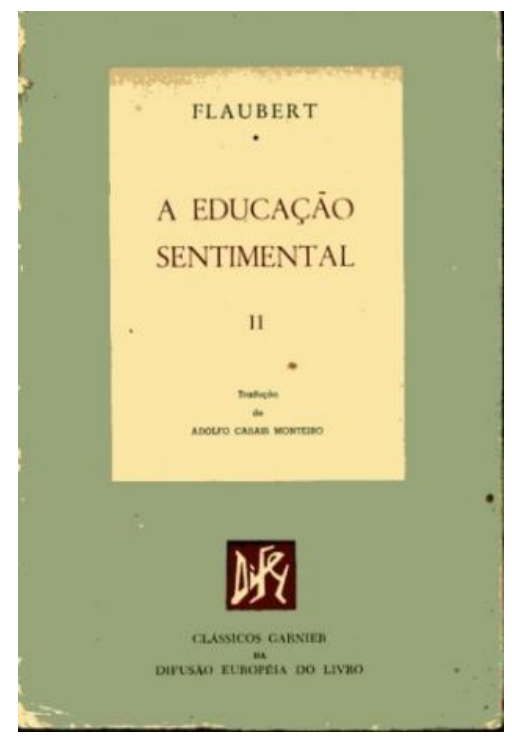

Embora este levantamento não inclua adaptações, cito de passagem uma curiosidade. Também em 1959, sai uma edição luxuosa de Madame Bovary, com “condensação literária" feita por Mário Donato e "visualização artística" (isto é, ilustrações) de Oswald de Andrade Filho na Coleção "Meu livro premiado", da série “Livros imortais", pela Edições Alarico. Vale por seu interesse bibliófilo, creio eu.

Retomando, em 1963 sai "Um coração simples", na antologia de Novelas francesas, pela Cultrix. Constam três tradutoras: Leyla Perrone-Moisés, Nelly Donato e Ruth Guimarães. Embora tenha contatado Leyla Perrone-Moysés, infelizmente não obtive esclarecimentos sobre a autoria da tradução. 
Em 1965, sai mais uma Madame Bovary, agora em tradução de Nair Lacerda, pela BUP (Biblioteca Universal Popular). Não localizei imagem de capa, mas dispomos de um exemplar em nosso acervo na Biblioteca Nacional.

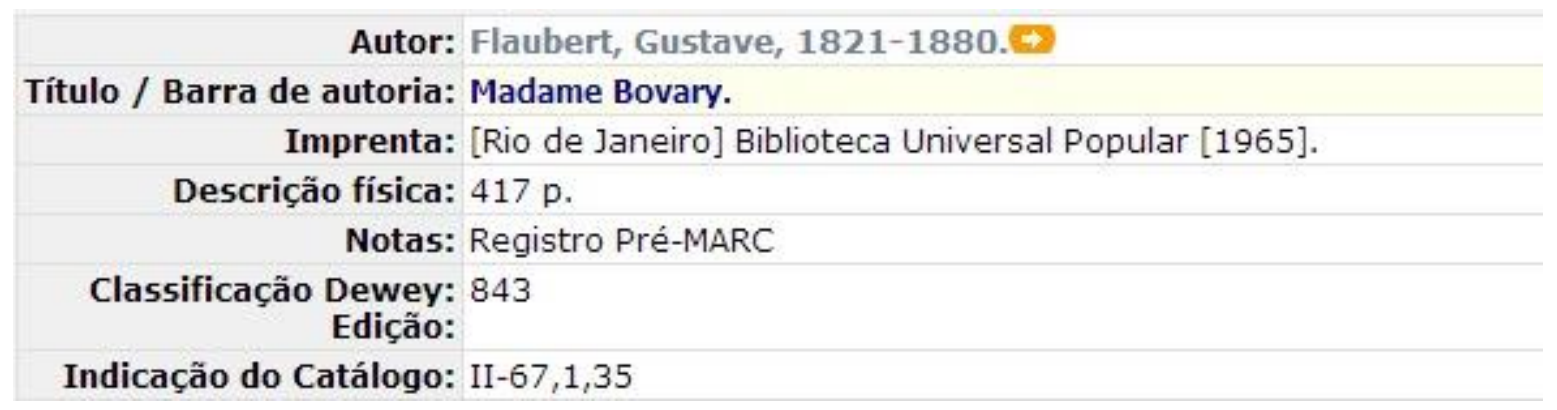

No ano de 1969, outra Madame Bovary, agora em tradução de Vera Neves Pereira, sai pela Bruguera:

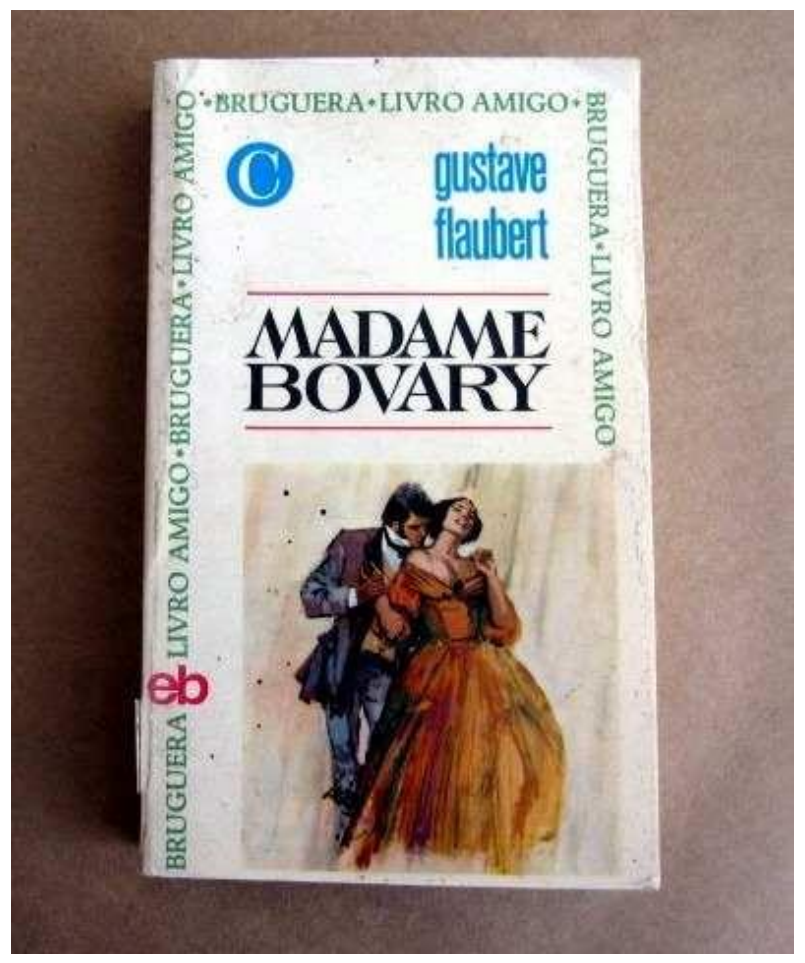

Em 1974, temos mais uma tradução de Três contos, pela Editora Três, em tradução de Luís de Lima (que adotou o título "Um coração singelo" para "Un cœur simple". A propósito, a Rocco volta a editar Um coração singelo, de Luís de Lima em 1986. 


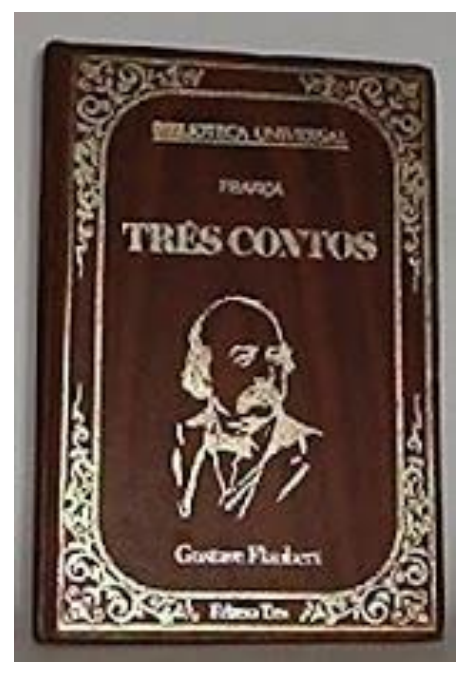

Em 1980, sai “Uma alma simples”, em tradução de Aurélio Buarque de Hollanda e Paulo Rónai, no volume IV do Mar de histórias pela Nova Fronteira (não sei se já fazia parte da antologia bem menos extensa, publicada entre 1945 e 1958 pela José Olympio).

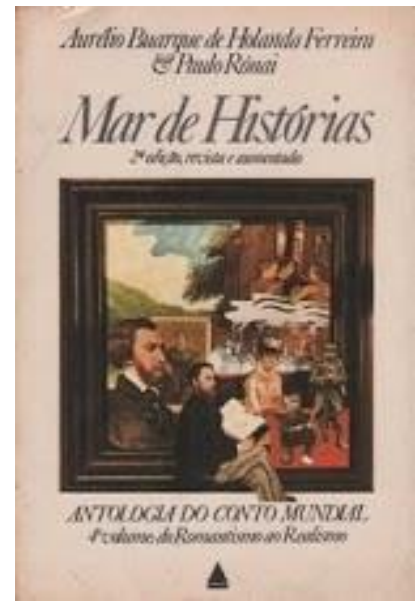

Em 1981, mais um volume com os Três contos, em tradução de Manuel Freitas Costa e Flávio Moreira da Costa, pela Francisco Alves (aqui, para o título do conto "Un cœur simple", também foi adotado "Uma alma simples"). Volta a ser lançado pela L\&PM em 2005, com créditos apenas em nome de Flávio Moreira da Costa. "Herodíade" é relançado em 2006 na antologia Os melhores contos bíblicos, pela Ediouro. 


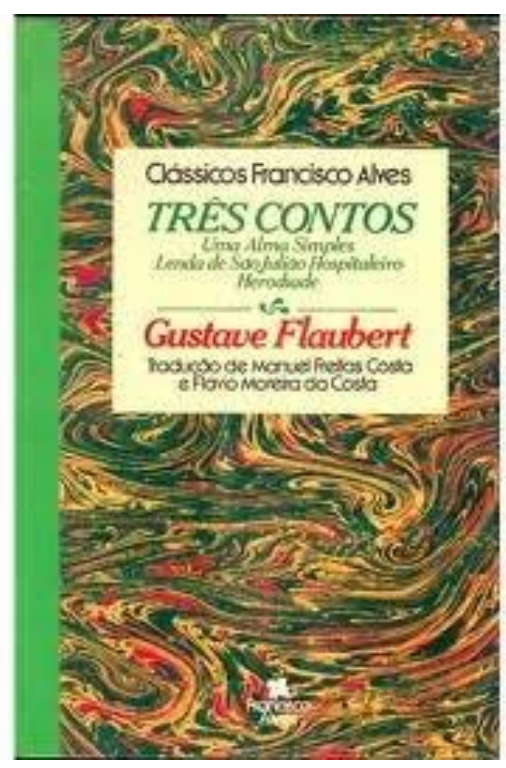

Em 1985, temos Salambô, em tradução de Mariajosé de Carvalho, pela Max Limonad:

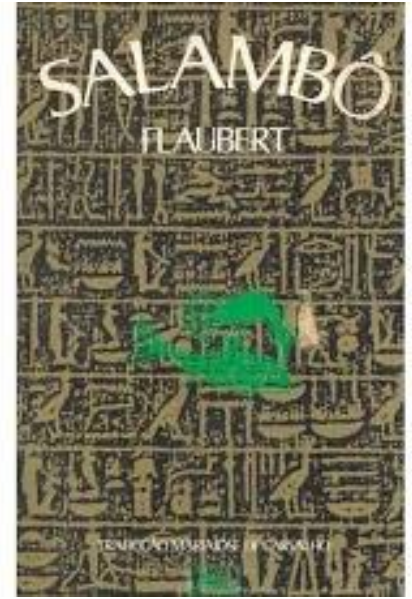

Também em 1985, sai outra tradução de Madame Bovary, agora de Sérgio Duarte, pela Ediouro:

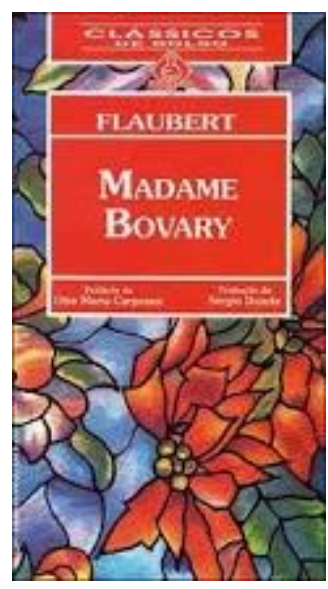


Em 1992, finalmente, temos um pouco de variedade. Sai um texto sobre a Comuna de Paris na coletânea Crônicas da Comuna, em tradução de Claudio Willer, pela Editora Ensaio:

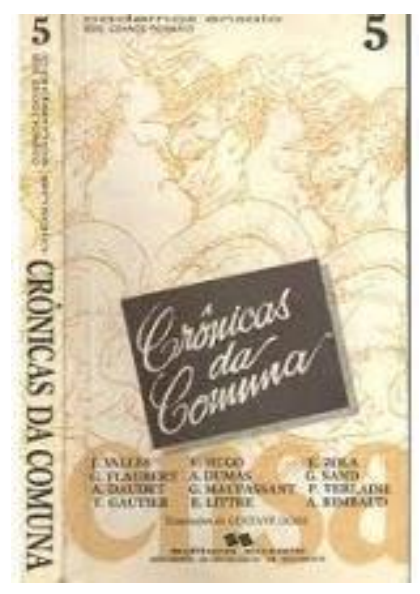

É lançada outra Madame Bovary, em 1993, com tradução de Fúlvia Moretto, pela Nova Alexandria:

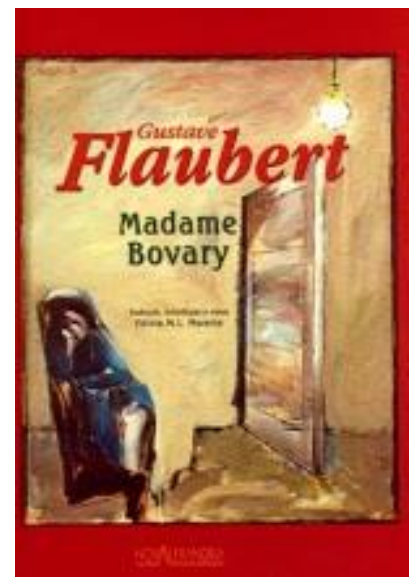

Também pela Nova Alexandria, em 1995, sai mais uma tradução de Dicionário das ideias feitas, agora por Cristina Murachco:

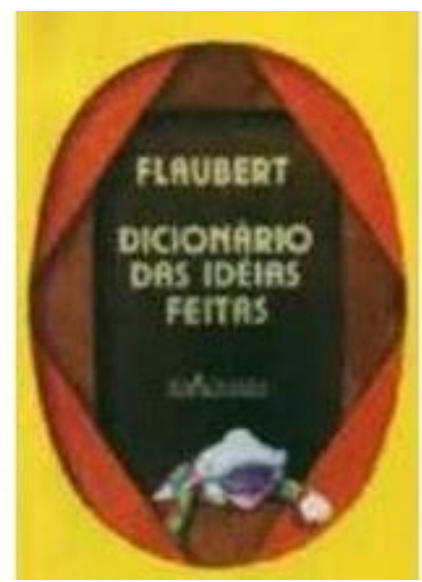


Em 1996, pela Paz e Terra, temos Um coração simples em tradução a seis mãos, por Clotilde Mariano Vaz, Daniel Vaz e Simia Katarina Rickmann:

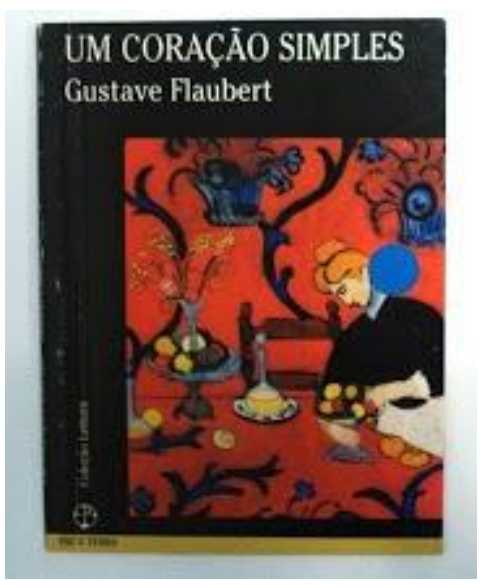

Em 2000, voltamos a ter um pouco de variedade com Novembro: seguido de treze cartas a Louis Bouilhet, em tradução de Sérgio Medeiros, pela Iluminuras:

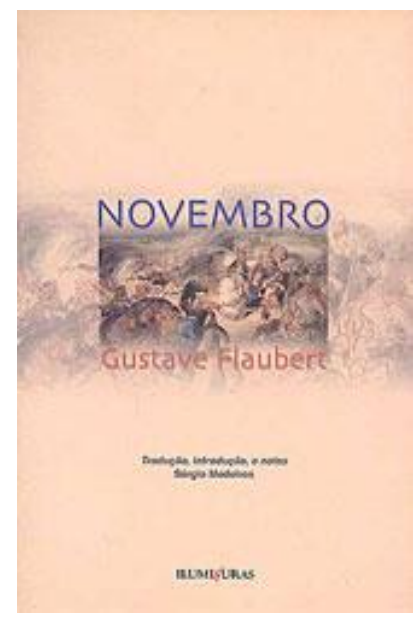

E em 2001 Bibliomania, em tradução de Carlito de Azevedo, pela Casa da Palavra:

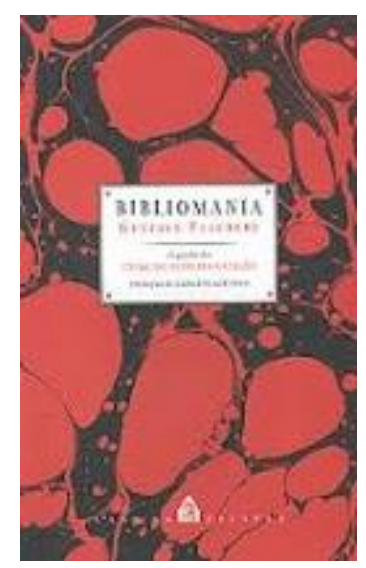


Em 2004, a mesma Casa da Palavra publica outra tradução da mesma "Bibliomania", agora integrando a coletânea A paixão pelos livros, em tradução de Júlio Silveira:

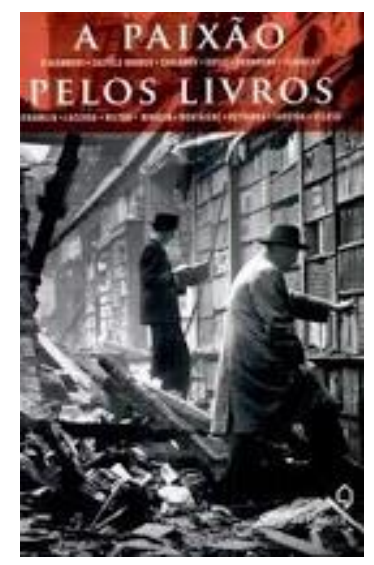

Também em 2004, aparecem (no plural) As tentações de santo Antão, em tradução de Luís de Lima, pela Iluminuras:

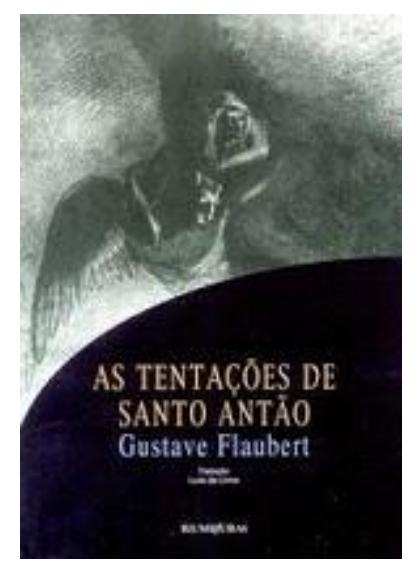

Apenas de passagem: vale notar que ambas as traduções optaram por verter "saint Antoine" por "santo Antão", de sabor mais lusitano, em lugar de "santo Antônio". Em 2004, sai uma Salambô pela Itatiaia, em sua série "Excelsior", sem qualquer menção ao tradutor. Infelizmente, a Itatiaia acabou desandando um pouco nos últimos dez, doze anos, e não me espantaria muito se fosse uma contrafação. 


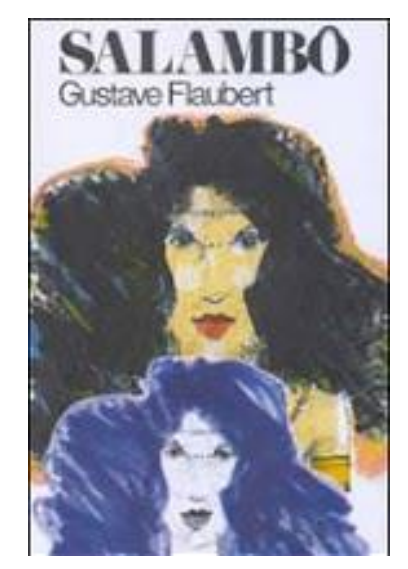

Em 2005, saem Cartas exemplares, em tradução de Carlos Eduardo Lima Machado, pela Imago:

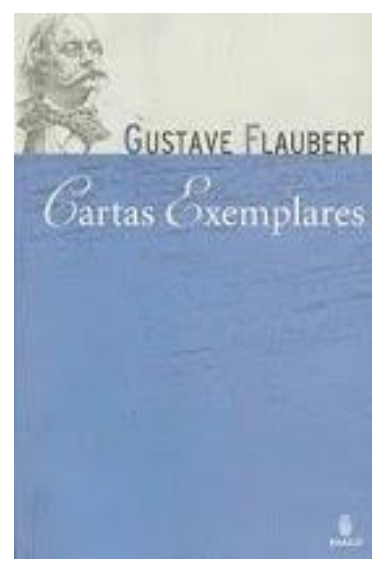

Em 2006, mais uma retradução de Trois contes, agora por Milton Hatoum e Samuel Titan Jr., pela Cosac Naify. (Variando o usual "lenda", temos aqui o título "A legenda de são Julião hospitaleiro"):

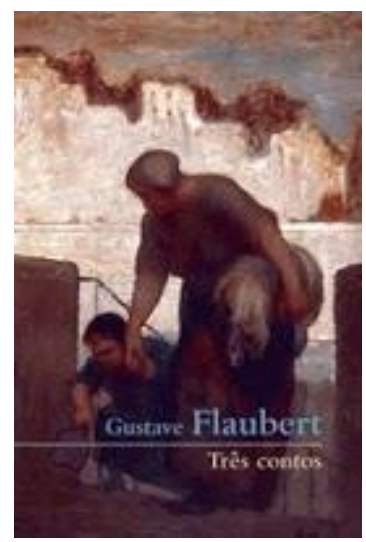


Outra novidade nesses anos é Gothica: contos juvenis de Gustave Flaubert, em tradução de Raquel de Almeida Prado, que sai em 2006 pela Berlendis \& Vertecchia:

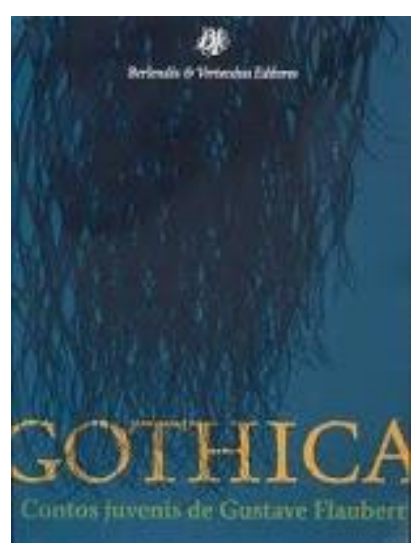

Por outro lado, ainda em 2006, sai pela Martin Claret uma vetustíssima tradução portuguesa de A educação sentimental, do final do século XIX, anônima, porém atribuída a João Barreira, que a bem dizer nem se insere neste nosso levantamento de traduções brasileiras.

Em 2007, temos uma nova tradução de Bouvard e Pécuchet, agora de Marina Apenzeller, pela Estação Liberdade:

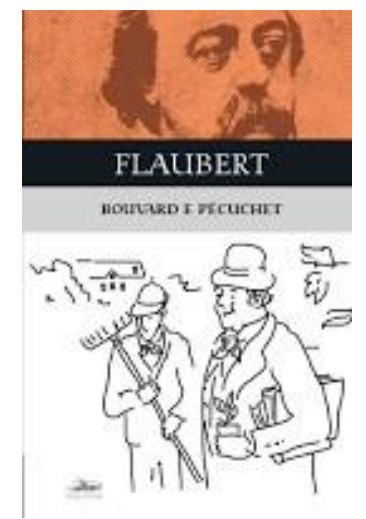

Em 2008, sai a tradução de Ilana Heineberg para Madame Bovary, pela L\&PM (a qual, tão logo se deu da conta da fraude que maliciosamente lhe impingira a Editora Nova Cultural, procedeu à recolha dos exemplares e contratou essa nova tradução):

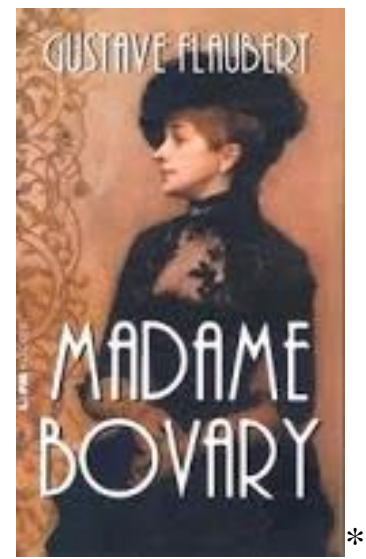


Em 2011, sai a nona tradução de Madame Bovary no Brasil, esta de Mário Laranjeira, pela Penguin/Companhia:

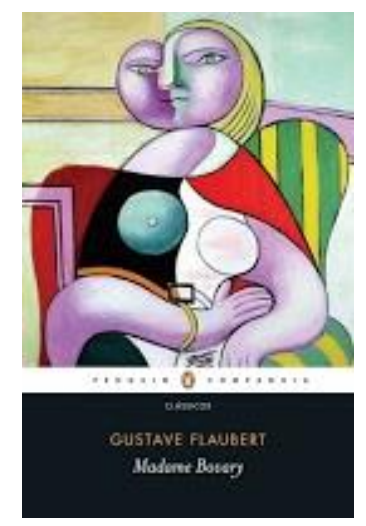

Em 2011, outra "Bibliomania", em tradução de Sandra M. Stroparo, pela Arte e Letra: estórias série M:

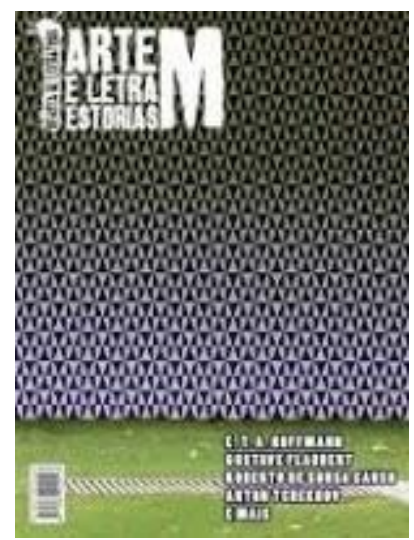

Em resumo, pelo levantamento aqui feito sobre a obra de Flaubert traduzida no Brasil, sem contar as adaptações infanto-juvenis, temos:

- nove Madame Bovary, além de duas anônimas, uma "condensação literária" e uma fraude grotesca;*

- cinco Três contos, e mais três Un cour simple avulsos com títulos variados;

- três "Bibliomania";

- duas Salambô, além de três anônimas e uma "revista";

- duas Educação sentimental, além de duas "revistas";

- dois Bouvard e Pécuchet;

- dois Dicionário de(as) ideias feitas;

- duas A(s)tentação(ões) de santo Antão;

- duas seletas de cartas; 
- uma "Comuna;

- um "Novembro";

- uma juvenília.

\footnotetext{
${ }^{1}$ Quanto às três passagens assinaladas com um asterisco, trata-se da edição de Madame Bovary publicada em 2002 pela Editora Nova Cultural em parceria com a Suzano e o Instituto Ecofuturo, em sua Coleção "Obras Primas". Foi uma publicação que teve tiragens altíssimas (de 80 a 120 mil exemplares para cada edição, conforme anunciou na época a coordenadora editorial da casa). A tradução vinha atribuída a um fantasmagórico "Enrico Corvisieri”, mas na verdade não passava de uma cópia adulterada da antiga tradução de Araújo Nabuco, de c. 1945. A Nova Cultural licenciou essa tradução fictícia para a L\&PM, a qual se viu lesada em sua boa fé e procedeu à recolha dos exemplares ao tomar ciência da fraude. Para um resumo desse caso, veja-se: <http://naogostodeplagio.blogspot.com.br/2008/11/httpwww.html>.
} 